\title{
Features of the influence of doping carbon sorbents,plant-based, iron nanoparticleson their behavior in the reaction of propane dehydrogenation
}

\author{
C Nikita A. Panurin, ${ }^{1+}$ Ekaterina B. Markova, ${ }^{1 *}$ Tatiana F. Sheshko, ${ }^{1}$ \\ Alexander G. Cherednechenko, ${ }^{1}$ Garry Z. Kaziev, ${ }^{2}$ and Julia Samoilenko ${ }^{1}$ \\ ${ }^{1}$ Department of Physical and Colloidal Chemistry. Peoples' Friendship University of Russia. \\ Miklukho-Maklaya St., 6. Moscow, 117198. Russia. \\ ${ }^{2}$ Department of Physical and Analytical Chemistry. Moscow State Pedagogical University. \\ Malaya Pirogovskaya,1/1. Moscow,119991.Russia.Email: Nikita.panuriin@mail.ru
}

\begin{abstract}
*Supervising author; ${ }^{+}$Corresponding author Keywords: Fe nanoparticles, propane dehydrogenation, carbon sorbents based on plant raw materials, natural coals.
\end{abstract}

\begin{abstract}
This paper describes the synthesis of highly active and selective catalysts based on natural coal: Jerusalem artichoke, camelina, rape and wheat, and their modification with nanosized iron, for cracking associated petroleum gases (APG) using the example of propane, for solving the ecological problem of environmental pollution and the economic problem of raw materials for the production of a huge range of polymer materials used by mankind in almost all spheres of life. With the help of APG catalysis, an environmental problem can be solved. By sending APG for processing to obtain light olefins for the production of polymeric materials. Currently, catalysts using nanoparticles show high performance in selectivity, product yield, and so on. As the physical properties of nanoparticles affect their catalytic properties, and how catalyst fabrication parameters can in turn affect these physical properties, nanocatalysts can be designed that are highly active, highly selective, and reasonably stable. Also activated carbons from natural plant raw materials have very good adsorption properties, but the nature and kinetics of adsorption are determined not only by the type of natural raw materials, but also by the temperature and other parameters of the technological characteristics of the carbon materials obtained.

Also, the use of catalysts in this area is environmentally beneficial, since it allows you to reduce the temperatures of the cracking processes and increase the yield of products of interest. The elemental composition of catalytic systems has been established. The acidity of catalytic systems of both natural coals modified with iron and simple natural coals has been established. A high catalytic activity of modified catalytic systems was revealed - the conversion of associated petroleum gas reaches a maximum at $900 \mathrm{~K}$. A high selectivity in the formation of olefins, about $95 \%$ at the maximum conversion, for the obtained catalysts was established.
\end{abstract}

\section{References}

[1] T.S. Pipa, A.Yu. Adzhiev. "Problems of increasing the use of associated gas and the regulatory framework governing this process." OJSC NIPIgazpererabotka. 2006. 60p. (russian)

[2] Flared Gas Utilization Strategy. Opportunities for Small-Scale Uses of Gas. The International Bankfor Reconstruction and Development. The World Bank. 2004. 113p.

[3] I.L. Moskvina, E.S. Ovechkina, F.Yu. Ovechkin. Regional ecology problems. 2006. No.3. P.17. (russian)

[4] Will Soutter, Nanocatalysis: New Dimensions in Catalysis// https://www.azonano.com/article.aspx?ArticleID=3079 accessed 13.05.2018.

[5] Revina A.A., Voropaeva N.L., Mukhin V.M. et al. Adsorbents based on active carbons modified (nano) particles of silver and iron. Abstracts. I Int. scientific and practical conf. Graphene and Related Structures: Synthesis, Production, and Applications. Tambov. 2015. P.165-167. (russian)

[6] D.V. Chekmar, D.A. Tanasyuk, N.L. Voropaeva, A.A. Revina. Influence of conditions for modification of carbon materials on the adsorption of silver NPs. Materials of the II All-Union conf. from int. participation and symposium "Actual problems of the theory of adsorption, porosity and adsorption selectivity." Moscow-Klyazma. 2015. P.76. (russian) 
[7] N.L. Voropaeva, V.M. Mukhin, A.A. Revina, C.A. Busev, V.V. Karpachev. Recultivation of plant wastes (straw) and obtaining (nano) chips with bactericidal properties based on them. GeoScience Engineering. 2015. Vol.LXI. No.3. P.1.

[8] A.A. Revina, O.G. Larionov, A.A. Volkov, O.V. Suvorova. Investigation by chromatographic and spectrophotometric methods of stable iron nanoparticles obtained by radiation-chemical synthesis in reverse micelles. Sorption and chromatographic processes. 2007. (russian)

[9] A.A. Revina, L.D. Belyakova, S.A. Parkaeva, O.V. Suvorova, M.O. Sergeev, V.I. Zolotarevsky. Study of the adsorption of palladium nanoparticles on silica by spectrophotometry and atomic force microscopy. Physical surface chemistry and material protection. 2010. Vol.46. No.6. P.448-454. (russian) 